\title{
USSR Organizational Structure, 1930s
}

In the absence of private property, all institutions in the USSR were technically part of the state. A key exception was the Communist party, which officially was a voluntary public (obshchestvennaia) organization. The party maintained a "cell" in every institution, and party administrations at all levels had departments paralleling those of the state. The USSR was thus a dualist party-state.

At the same time, the state structure was multiple. As a result, although all lower-level organizations were subordinated to upper ones in a pyramid, the parallelism of the party-state pyramids and the multiplicity of the state itself created overlapping jurisidictions. It also needs to be borne in mind that the Soviet Union was nominally a federation, with Magnitogorsk located in the Russian republic (RSFSR). Only all-union bodies bore the designation "USSR."

\section{PARTY PYRAMID}

ALL-UNION COMMUNIST PARTY (BOLSHEVIKS)

All-Union Party Congress. Irregularly convened. Formally the highest body of the party. Served between sessions by a Central Committee.

USSR Central Committee (CC). Dominated by its nominally subordinate political bureau (politbureau) and administrative secretariat. Headed in the 1930 by General Secretary Joseph Stalin.

Urals provincial party committee (obkom). Divided in three in 1934.

Cheliabinsk provincial party committee (obkom). Formed out of the Urals oblast in 1934. Headed by the obkom bureau. 
Magnitogorsk city party committee (gorkom). Headed by the gorkom bureau.

Urban-district party committees (raikom).

Primary party organizations (PPOs). The lowest level of party organization. Called "cells" before 1934 .

Communist party youth league (Komsomol). The apprentice organization for the party.

The RSFSR did not have its own Communist party structure; obkoms in the RSFSR were subordinated directly to the USSR Central Committee.

\section{STATE PYRAMID}

\section{LEGISLATIVE AND EXECUTIVE}

All-Union Congress of Soviets. Biannual congress of representatives of local soviets. Replaced in 1936 by the Supreme Soviet.

USSR Supreme Soviet. Permament body of elected representatives.

All-Union Congress of Soviets/USSR Supreme Soviet Central Executive Committee (TsIK).

RSFSR All-Union Congress of Soviets/Supreme Soviet and Central Executive Committee.

Cheliabinsk provincial soviet and soviet executive committee.

Magnitogorsk city soviet and soviet executive committee.

Urban-district soviets.

Soviet sections (volunteers).

City-soviet planning commission.

At all levels, the full soviet, consisting of popularly elected representatives, was nominally charged with policy formation; executive committees, elected by the soviets, were responsible for implementation. Thus, soviets technically had both legislative and executive power. The head of the USSR Supreme Soviet was the head of state.

\section{GOVERNMENT AND BUREAUCRACY}

USSR Council of People's Commissars (Sovnarkom). Coordinating body of the bureaucracy, made up of the heads of each commissariat. Essentially the Soviet government. The chairman of Sovnarkom held a rank equivalent to prime minister.

Council of Labor and Defense (STO). High-level special government com- 
mission, technically subordinate to Sovnarkom but in practice above it. Temporarily abolished in 1937.

RSFSR Sovnarkom. Because the Magnitogorsk factory had all-union status, it was subordinated directly to the USSR, not the Russian republic.

People's Commissariat of Heavy Industry (NKTP). One of the commissariats represented on the USSR Sovnarkom. It owned and supervised most of the economy. Replaced the Supreme Council of the National Economy (Vesenkha) in 1932.

Main Administration of the Metallurgical Industry (GUMP). A subdivision of the Commissariat of Heavy Industry. Converted to the Commissariat of Ferrous Metallurgy (NKChM) when NKTP was divided into several commissariats in 1939.

Magnitogorsk Metallurgical Complex (MMK). Factory and mine. Under the Main Administration of Metal Industry.

Everyday-Life Administration (KBU). A division of the Magnitogorsk Metallurgical Complex. Renamed Municipal Economy Administration (UKKh) in 1938.

People's Commissariat of Internal Affairs (NKVD). Security police. Represented on the USSR Sovnarkom; in practice subordinated directly to the Communist party secretariat. For most of the 1930s, the regular police, called the militia, were attached to the NKVD. Prior to 1934, the security police was organized as an independent commission called the Main Political Administration (GPU). Both the NKVD and the GPU were colloquially referred to by the acronym for their predecessor organization, the "Cheka."

Provincial NKVD.

Magnitogorsk NKVD. Controlled the administrations of the Magnitogorsk Corrective Labor Colony (ITK) and Special Labor Settlement (Spetstrudposelok).

NKVD boards and troika. Summary sentencing bodies for crimes deemed to involve counterrevolution.

People's Commissariat of Justice (Narkomiust). Headed by USSR general procurator.

Provincial procurator.

Magnitogorsk procurator.

USSR Supreme Court. 
Provincial court.

Magnitogorsk people's courts.

Comrade courts.

Narkomiust had jurisdiction only over non-counterrevolutionary crimes. The procurator technically had supervisory power over the NKVD, but the NKVD effectively resisted outside supervision of its operation. Railroads and waterways had a separate procurator and court system.

People's Commissariat of Municipal Economy (Narkomkhoz). Represented on USSR Sovnarkom. Completely eclipsed in Magnitogorsk by NKTP.

People's Commissariat of Trade (Narkomtorg). Represented on USSR Sovnarkom. Responsible for urban supply.

Provincial trade (Obltorg).

Magnitgorsk trade (Magnittorg).

Central Workers' Cooperative (TsRK). Reorganized and renamed the Department of Workers' Supply (ORS) in 1933.

City dining trust (Narpit).

City food processing complex.

Cooperatives.

State Planning Commission (Gosplan). Important for industrial operation and supply, parallel to NKTP.

State Institute for the Design of Metallurgical Factories (Gipromez), in Leningrad. Small role in the design of the Magnitogorsk factory.

Urals branch of Gipromez. Renamed Magnitostroi in 1927.

Magnitostroi. Design and construction trust (also the name for the construction site). Subordinated to GUMP. Merged with MMK in 1934; reinstituted as a separate trust in 1936 .

Koksostroi. Coke plant construction, merged with Magnitostroi in 1933.

Mining Administration (GRU). Merged with Magnitostroi in 1933.

"Subcontracting" trusts (Stalstroi, etc.). Abolished in 1932 with the formation of GUMP.

State Institute for the Planning of Cities (Giprogor). Organization that employed the German architect Ernst May.

Oblast urban planning (Oblproekt).

City urban planning (Gorproekt). 
All-Union Central Council of Trade Unions (VTsSPS). Trade unions were responsible for access to recreation facilities, accident insurance, pensions and other benefits.

USSR Metal Workers Union.

Provincial branch of the Metal Workers Union.

Magnitogorsk branch of the Metal Workers Union.

\section{COMBINED PARTY AND STATE AGENCY}

Central Control Commission and Workers' and Peasants' Inspectorate (TsKK-RKI). Combined party control commission and state commissariat (Rabkrin) with wide investigatory powers. Parallel to the GPU. Abolished in 1934 when the GPU was reorganized into the NKVD. In 1935 separate party and state control commissions were created.

Oblast control commission (ObIKK). Abolished in 1934.

City control commission (GorKK). Abolished in 1934. 
This page intentionally left blank 